\section{Weeping Dragon, a Unique Ornamental Citrus}

Kim D. Bowman ${ }^{1}$

U.S. Horticultural Research Laboratory, USDA, ARS, 2001 S. Rock Road, Ft. Pierce, FL 34945

Additional index words. sweet orange, ornamental, cultivar, breeding, genetics similar to leaves of other first generation hybrids between citrus and Poncirus trifoliata. The center leaflet, side leaflet, and petioles of 'Weeping Dragon' are significantly longer and wider than those plant parts on its parent 'Flying Dragon', as well as 'Carrizo', a hybrid of similar parentage (Table 1). The other parent, 'Cipo', has unifoliolate leaves with articulated winged petioles, and has a leaf blade that is significantly longer and wider than the center leaflet of 'Weeping Dragon', while having a petiole
'Weeping Dragon' is a new ornamental citrus cultivar released 30 June 2016 (Bowman, 2016) by the Agricultural Research Service (ARS) of the U.S. Dept. of Agriculture. The major positive attributes of this unique ornamental citrus scion are the combination of strongly contorted and weeping growth traits in a moderately vigorous and healthy, very small orange-like tree, especially suited for use as an ornamental specimen in a pot or the ground. The cultivar can be easily propagated by grafting clean budwood onto a standard citrus rootstock cultivar.

\section{Origin}

This ornamental citrus scion cultivar originated from a 1988 cross of 'Flying Dragon' trifoliate orange (Poncirus trifoliata) $\times$ 'Cipo' sweet orange (Citrus sinensis) made at the USDA A. H. Whitmore Foundation Farm (Groveland, FL) by Dr. Herb Barrett of the USDA, ARS, USHRL, FL. Hybrid seeds from the cross were planted at the Whitmore Foundation Farm in 1990 and grown in the field until the hybrid that became 'Weeping Dragon' was selected for further study. Selection and evaluation of 'Weeping Dragon' was completed by Dr. Kim Bowman under the code number US-1111, and evaluation was completed at the Whitmore Foundation Farm and the USHRL in Ft. Pierce, FL between 1992 and 2016.

Leaf and spine measurements were collected from 15 separate nodes on currentseason hardened shoots on one mature tree for each of 'Weeping Dragon', 'Flying Dragon', 'Cipo', and 'Carrizo' citrange (Citrus sinensis $\times$ Poncirus trifoliata) in Sept. 2016. Fruit measurements were collected from 3 to 5 mature fruit from trees of the four cultivars in Sept. 2016.

\section{Description}

Trees of 'Weeping Dragon' have trifoliolate leaves with articulated winged petioles,

Received for publication 23 Nov. 2016. Accepted for publication $21 \mathrm{Feb} .2017$.

Mention of a trademark, warranty, proprietary product, or vendor does not imply an approval to the exclusion of other products or vendors that also may be suitable.

${ }^{1}$ Corresponding author. E-mail: kim.bowman@ars. usda.gov.
Table 1. Leaf, spine, and fruit characteristics of fruiting trees for 'Weeping Dragon', its two parents ('Cipo' and 'Flying Dragon'), and another hybrid of similar parentage ('Carrizo').

\begin{tabular}{lcccc}
\hline Trait & Weeping Dragon & Cipo & Flying Dragon & Carrizo \\
\hline Center leaflet length $(\mathrm{mm})$ & $85 \mathrm{~B}$ & $96 \mathrm{~A}$ & $39 \mathrm{D}$ & $56 \mathrm{C}$ \\
Center leaflet width $(\mathrm{mm})$ & $46 \mathrm{~B}$ & $61 \mathrm{~A}$ & $21 \mathrm{D}$ & $34 \mathrm{C}$ \\
Side leaflet length $(\mathrm{mm})$ & $58 \mathrm{~A}$ & - & $28 \mathrm{~B}$ & $30 \mathrm{~B}$ \\
Side leaflet width $(\mathrm{mm})$ & $30 \mathrm{~A}$ & - & $16 \mathrm{~B}$ & $19 \mathrm{~B}$ \\
Petiole length $(\mathrm{mm})$ & $30 \mathrm{~A}$ & $18 \mathrm{~B}$ & $21 \mathrm{~B}$ & $19 \mathrm{~B}$ \\
Petiole width $(\mathrm{mm})$ & $14 \mathrm{~A}$ & $5 \mathrm{~B}$ & $5 \mathrm{~B}$ & $5 \mathrm{~B}$ \\
Spine length $(\mathrm{mm})$ & $62 \mathrm{~A}$ & $6 \mathrm{C}$ & $24 \mathrm{~B}$ & $8 \mathrm{C}$ \\
Spine curvature (degrees) & $193 \mathrm{~A}$ & $0 \mathrm{~B}$ & $25 \mathrm{~B}$ & $0 \mathrm{~B}$ \\
Fruit length $(\mathrm{mm})$ & $61 \mathrm{~B}$ & $73 \mathrm{~A}$ & $40 \mathrm{C}$ & $47 \mathrm{BC}$ \\
Fruit diameter $(\mathrm{mm})$ & $53 \mathrm{~B}$ & $69 \mathrm{~A}$ & $42 \mathrm{C}$ & $49 \mathrm{BC}$ \\
\hline
\end{tabular}

Mean separations for significant ANOVA within rows were by Duncan's multiple range test at $P<0.01$

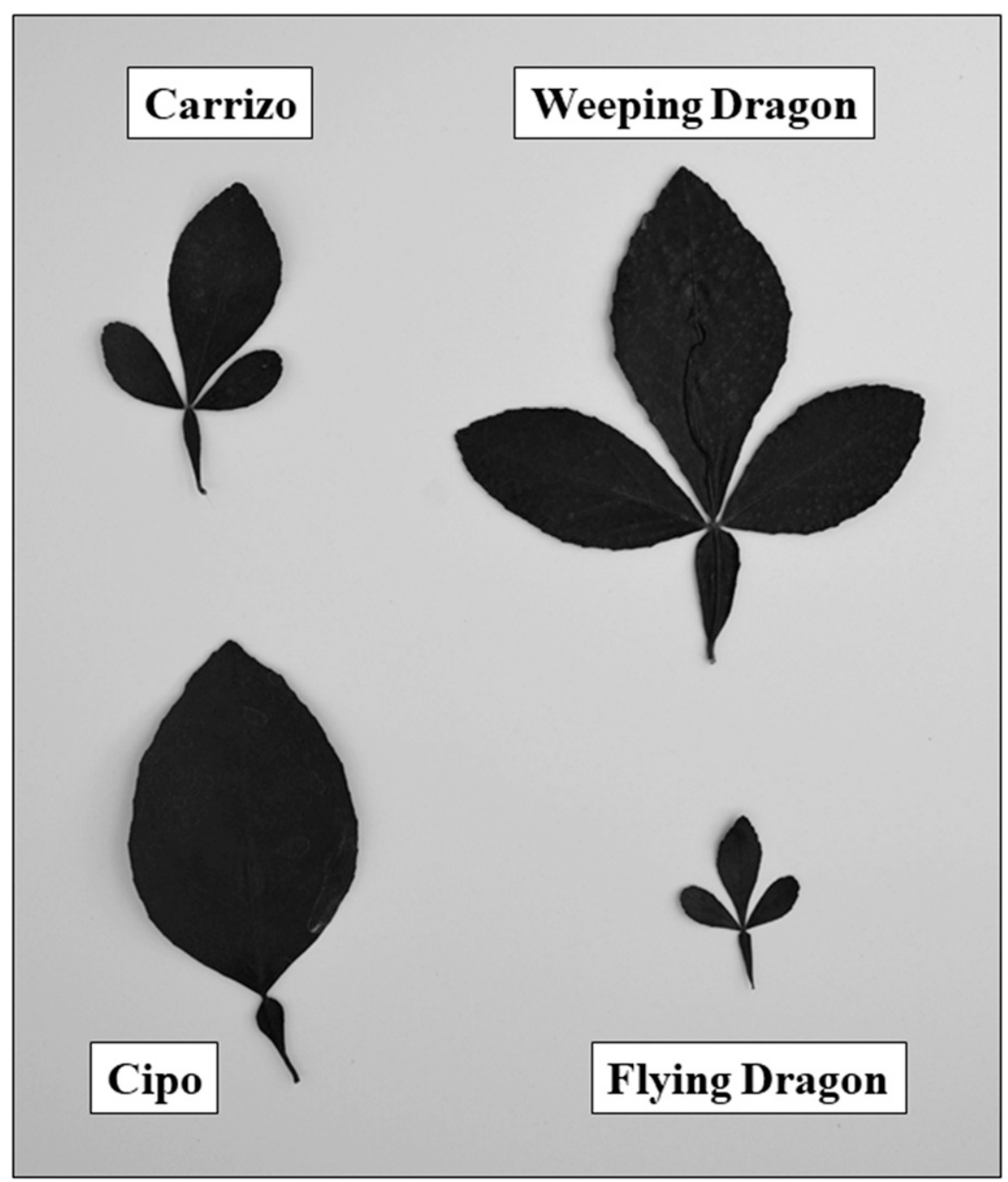

Fig. 1. Mature leaves from fruiting trees of 'Weeping Dragon', 'Carrizo', 'Cipo', and 'Flying Dragon'. 


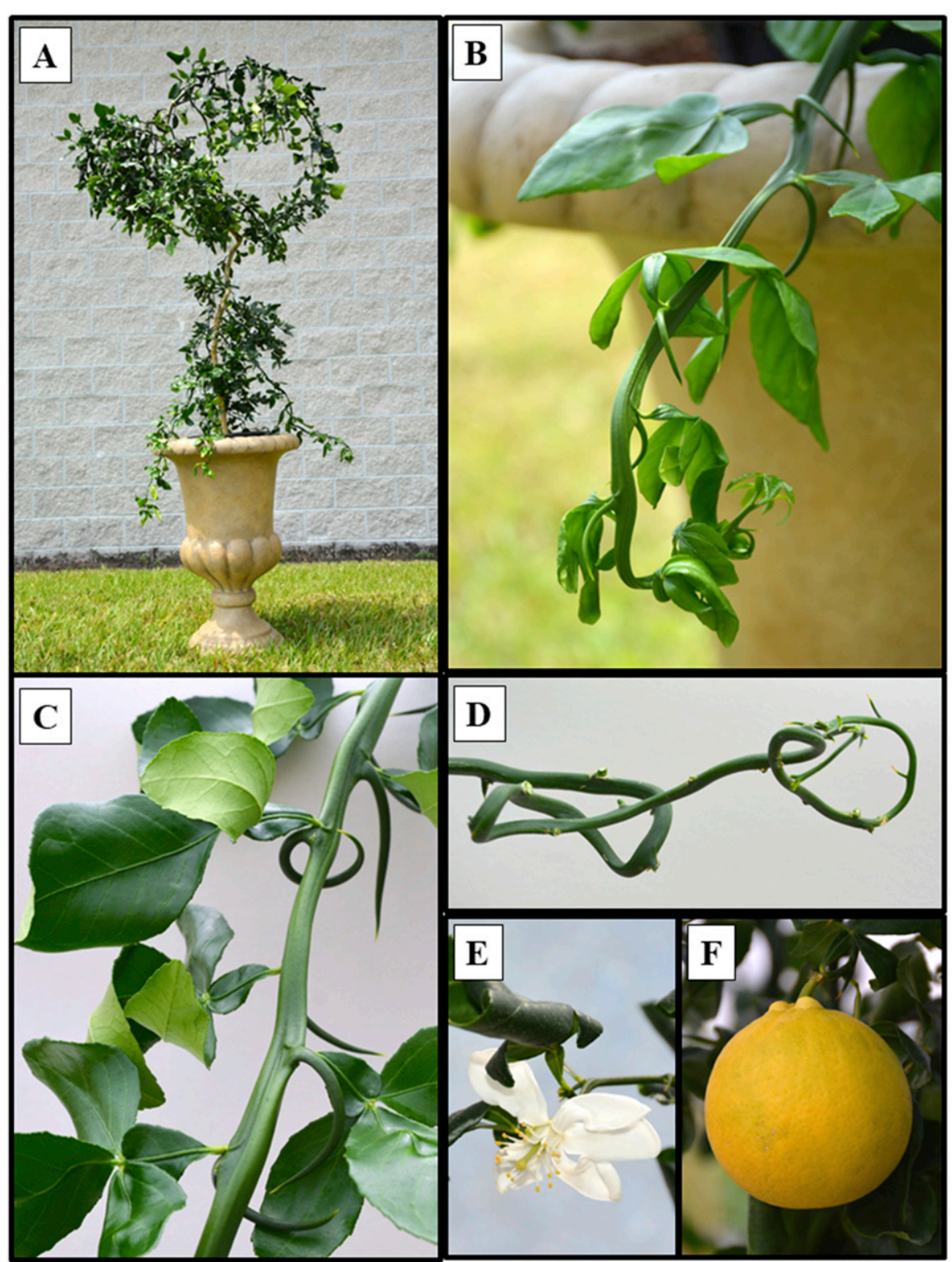

Fig. 2. (A) Three year old potted tree of 'Weeping Dragon', growing on 'US-812' rootstock. The tree is $1.3 \mathrm{~m}$ tall above the pot. (B) Young weeping flush, showing weeping growth with upturned shoot tip and hooked thorns. (C) Older weeping branch, showing contorted curled leaves, and variably hooked thorns. (D) Mature shoot with leaves and branches removed to show irregular stem twisting and loops. (E) Open flower on mature flush, showing dark green curled leaves. (F) Fruit of 'Weeping Dragon' partially colored yellow-orange on 9 Nov.

that is significantly shorter and narrower. Leaf appearance for 'Weeping Dragon' is visibly quite different from either parent or 'Carrizo' (Fig. 1). In addition to differences in dimensions, 'Weeping Dragon' leaves are somewhat distinctive in having a darker green color than most similar hybrids, and having an irregularly contorted, curled, or twisted appearance. In the absence of a freeze, trees do not usually defoliate, or lose the leaves from the previous season until after new flush and leaves have emerged in the spring. Trees of 'Weeping Dragon' are compact, attractive, and exotic in overall appearance (Fig. 2A).

Single spines are found in most leaf axils, and are highly variable, but often very long and hooked, somewhat resembling the mythical claws of a dragon (Fig. 2B and C). The right, but other new flush weeps or will grow straight down for $20 \mathrm{~cm}$ or more before turning to the horizontal. Some training of trees during growth may be necessary to develop an upright stature because of this pronounced weeping growth.

Flowers are white and similar in size and appearance to sweet orange (Fig. 2E). Fruiting is erratic, but when present, fruit is similar in size to that of 'Carrizo', with a length and diameter intermediate between the fruit of the two parents (Table 1), and yellow-orange in color at maturity (Fig. 2F). The quality of fruit from 'Weeping Dragon' has not been evaluated, but it should not be considered suitable for consumption. Propagation of 'Weeping Dragon' by seed has also not been evaluated. The potential for 'Weeping Dragon' as a novelty ornamental is outstanding. The overall effect from the combination of large curly dark-green leaves, large strongly-hooked thorns, severely contorted stems, and weeping habit is a unique and attention-getting small tree, ideal as a focus specimen for the patio or landscape.

It should be noted that the contorted and weeping traits were clearly derived by sexual recombination between the two parents of 'Weeping Dragon'. The seed parent, 'Flying Dragon', exhibits the contorted growth habit, including hooked thorns and twisted shoot growth. These traits have been studied and demonstrated to be inherited among progeny, especially when 'Flying Dragon' is used as the seed parent (Cheng and Roose, 1995; Yoshida, 2005). The pronounced weeping habit of the pollen parent, 'Cipo', has been described (Bowman, 1994), and has been demonstrated to be recovered among progeny when 'Cipo' is used as the pollen parent (Bowman, 1997). 'Weeping Dragon' was selected from one particular progeny group of this parental combination because it presented a particularly attractive combination of those two unique genotypes in a form that accentuates and beautifies the dramatic novelty of the combined traits.

'Weeping Dragon' was selected and evaluated as a novelty ornamental cultivar, and as such, it is assumed that it will typically receive frequent attention and excellent care by botanic gardens and adventurous home gardeners who value its unique appearance. As a novelty scion cultivar, its tolerance of common biotic and abiotic conditions is considered acceptable, but these attributes were not thoroughly studied. Trees of 'Weeping Dragon' for study were grafted onto 'US812' and 'Carrizo' rootstocks, and both appeared completely compatible with this scion for long-term growth. The name 'Weeping Dragon' was chosen to represent the combination of the weeping trait, along with the contorted trait from 'Flying Dragon', as well as because of the way the large hooked thorns and drooping twisted stems might resemble a mythological dragon crying in repose. 


\section{Availability}

Source plant material for 'Weeping Dragon' is available from the Florida Bureau of Citrus Budwood Registration clean budwood program (3027 Lake Alfred RoadHighway 17, Winter Haven, FL 33881) and will be distributed, according to Florida Department of Agriculture and Consumer Services regulations. Plant tissue for research, as well as additional information on 'Weeping Dragon' may be obtained from Kim D. Bowman, USDA, ARS, USHRL, 2001 South Rock Road, Ft. Pierce, FL 34945 (kim.bowman@ars.usda. gov). Genetic material of this release will be deposited in the National Plant Germplasm System where it will be available for research purposes, including development and commercialization of new cultivars. Appropriate recognition should be made if this germplasm contributes to the development of a new breeding line or cultivar.

\section{Literature Cited}

Bowman, K.D. 2016. Release of the weeping dragon, ornamental citrus. US Department of Agriculture, ARS, Washington, D.C.
Bowman, K.D. 1994. 'Cipo' sweet orange and its unique growth habit. Fruit Var. J. 48:230-234.

Bowman, K.D. 1997. Inheritance of procumbent habit from 'Cipo' sweet orange in crosses with 'Clementine' mandarin. J. Amer. Soc. Hort. Sci. 122:360-367.

Cheng, F.S. and M.L. Roose. 1995. Origin and inheritance of dwarfing by the citrus rootstock Poncirus trifoliata 'Flying Dragon'. J. Amer. Soc. Hort. Sci. 120:286-291.

Yoshida, T. 2005. Inheritance of crooked twig and thorn trait from Flying Dragon trifoliate orange (Poncirus trifoliata var. monstrosa $[\mathrm{T}$. Ito] Swingle). J. Jpn. Soc. Hort. Sci. 74(3): 189-195. 